\title{
Investigation of the practices in learning centers of pre-school education institutes
}

\author{
Şermin Metin \\ Hasan Kalyoncu University, Gaziantep, Turkey, sermin.metin@hku.edu.tr
}

\begin{abstract}
The study used both the qualitative and quantitative research method, aims to determine the practices regarding learning centers in the preschool class. The sample is selected from preschool teachers who are worked in Aydın. The (Ministry of Education) schools are kindergartens in 27 primary schools and 5 preschools. In sum, 16 volunteer teachers, who is 5 from kindergarten and 11 from kindergarten of other schools are selected. For data collection, "The Learning Centers Review and Observation Form" that is developed by researcher is used. The first part of the learning centers review and observation form involves observations, the information about the class and the teacher, and the teacher's opinions regarding learning centers, the second part involves observations about "design of learning centers", and the third part has observations about "application of learning centers". For data analysis, descriptive and content analysis methods are used. First, the themes and codes are defined and then the themes are coded. As the result of study, teachers' level of skills regarding the learning center design and practice is found as low.
\end{abstract}

Keywords Learning center, free time, class design, preschool education

\section{Okul öncesi eğitim kurumlarında bulunan öğrenme merkezlerindeki uygulamalarin incelenmesi}

ÖZ Okul öncesi eğitim kurumlarında bulunan öğrenme merkezlerindeki uygulamaların saptanması amacıyla yapılan çalışma nitel ve nicel araştırma yöntemlerinin kullanıldığı karma bir yöntemle gerçekleştirilmiştir. Çalışma grubunu Aydın il merkezinde Milli Eğitim Bakanlığı'na bağlı 6 bağımsız anaokulu ile bünyesinde anasınıfı bulunan 27 ilköğretim okul içerisinden seçilen öğretmenler oluşturmuştur. Çalışma gönüllü olarak katılan 11 anasınıfı, 5 bağımsız anaokulundan birer öğretmen olmak üzere 16 öğretmen ile gerçekleştirilmiştir. Araştırmada veri toplama aracı olarak "Genel Bilgi Formu" ile araştırmacı tarafından hazırlanan yarı yapılandırılmış “Öğretmen Görüşme Formu” ve “Öğrenme Merkezleri Değerlendirme Gözlem Formu” kullanılmıştır. Genel bilgi formunda öğretmen ve sınıfına yönelik beş soruya yer verilmiştir. Öğretmen Görüşme Formu öğretmenlerin öğrenme merkezlerini düzenleme ve kullanımına ilişkin altı sorudan oluşmaktadır. Öğrenme Merkezleri Değerlendirme Gözlem Forumu'nda ise "merkezlerin düzenlenmesine yönelik 11, "merkezlerin kullanılmasına" yönelik sekiz olmak üzere toplam 19 gözlem durumuna yer verilmiş, gözlem durumları "var", "yok", "kısmen" biçiminde derecelendirilmiş ve açıklama kısmı eklenmiştir. Verilerin analizinde betimsel ve içerik analizi yöntemleri kullanılmıştır. Araştırmanın amacı kapsamında gerekli temalar ve kodlar belirlenmiş ve veriler bu kodlar üzerinden tanımlanmaya çalışılmıştır. Araştırma sonucunda çalışmaya katılan öğretmenlerin öğrenme merkezlerini düzenleme ve kullanımına ilişkin beceri düzeylerinin düşük olduğu görülmüştür. 


\section{INTRODUCTION}

Education is a dynamic structure that consists of elements such as education context, personnel, physical setting, learning equipment, special designing. The appropriate of the physical setting/conditions, its consistency with the program content and the objectives, and its being designed to cooperate with all elements affecting learning is an inseparable part of the effective learning/teaching process. That is why; physical setting plays a significant role on the quality of preschool education (Karaküçük, 2008; Mashborn, 2008). Designing physical environment and the materials in pre-school years is the first and important step of education. Physical conditions have significance in teaching children how to play together, supporting their learning skills and increasing the quality of learning. Surfacing the existing capacities of children who are in contact with the physical environment they live in, is not limited to the facilities the environment provides them (Sanoff, 1995; Woolfolk, 2012). Physical environment that is accepted as the second teacher affects the development of the child as a whole and support their development at an optimum level with its characteristics such as safety, comfort, accessibility, enforcement, motivation, directionality/manipulation, identity, privacy to meet all the physiological and psychological needs and expectations of the children (Maxwell, 2007; Sanoff, 1995; Stankovic \& Stojic, 2007).

Learning centers that are the main component of the learning environment and defined as learning area, activity area and, activity corner are defined as a place where children work in small groups or individually to facilitate children's trial and invention. Learning centers have the characteristic of a special environment with varying materials, certain physical borders where a number of experience and activities take place (MEB, 2013; Beaty, 2013; Biçer, 1994; De Carvalho, 2004; Diffily, Donaldson \& Sassman, 2001; Prevast, 2003; Sanoff, 1995; West, 2011; Yalçın, 2011). While Caples (1996) mentions children's need for larger areas where they can deal with a number of activities and do inventions, Sanoff (1995) states that learning centers that are defined in different ways such as activity area, centers, corners, stations or game places in different countries and programs, are the designed forms of game areas that include different but parallel activities.

Designing learning centers is seen as a key factor for a successful education program (Butin and Woolums, 2009). For this reason, the learning centers design and time use should be well planned to ensure benefit of children at the desired level. The flexibility is an important point while creating learning centers. Because the children sage, developmental level, growth, besides needs and interests the relations with each other, specific characteristics for some learning centers as natural light, how many learning centers will be created and the learning centers width according to the child number and class size should be considered (Çakır, 2011; Null \& Sima, 2000; Ömeroğlu-Turan \& Turan, 1998). The classes with two learning centers oral ternating the use of the centres in small classes or the classes that the children size are extreme, will make learning centers use effective (MEB, 2013; Kandır, 2001). Another important point while designing learning center should be to create spatial differences that provide different learning opportunities and different activities according to the children interests (Çakır, 2011; Diffily at al., 2001; Knopf \& Welsh, 2010; Poyraz \& Dere, 2001). Moving lockers or compartments, different flooring materials, different wall colors, lighting changes, ceiling, or visual cues (such as flor height) of learning centers should be used to create the spatial differences (Diffily et.al., 2001; Pool \& Carter, 2011; Stephens; 1996). Mills (1998) define that spatial differences should provide children material use, peer interaction, visibility and easy accessibility by children. The learning centers that are less interesting should be more attractive (Beaty, 2013; Diffily et. al., 2001; MEB, 2013; Prevost, 2003).

The learning centers, as a need of program context and to keep up, in the framework of different themes and concepts, should be developed, changed and renewed as needed; the interest to the learning centers should mainted by changing materials, using the concrete and real materials, and related to the daily and real life experiences (Diffily et.al., 2001; Lundgren, 1998; Moyer, 2001; Stephens, 1996; West 2011). Because of the difficulty of being and working in the same center for each child, the center choice and the explanation of how center choices made, is needed. by this practicum, the children can work on the centers they choice and change the center when the center is empty, so the children can use all the centers and the chaos is avoided (Beaty, 2013; Diffily et al. 2001; Güler, 2007; Kocamanoğlu, 2014; West, 2011 Çakır, 2011; Mills, 1998; Moyer, 2001; Pool \& Carter, 2011) According to West (2011), the centers should be arranged, that 3-4 children can play together and children change in terms of centers and play 
friend is possible. Provesto (2003), stated that the learning centers should give opportunity for children play with different groups in different centers and children work with all the friends in class. the other point in terms of the learning centers effectiveness, how children use the learning centers, the points to consider while using the centers (being quiet, appropriate use, use of center as individual and/ or in groups for works for a period of time, center choice and use of materials, clean up the centers) should be decided with children, and supported by visual stimuli for children independent use. It is essential to guide children to follow up the rules (Anonymous, 2010 Beaty, 2013; Diffily et al. 2001

Learning centers in the pre-schools that have monotonous education provide children who are in need of dealing with different activities in varying fields, being active and mobile in the setting with independent work opportunities in many fields (Anonymous, 2010). Broadhead (2004), Diachenko (2011), McInnes (2009), Samuelsson and Carlsson (2008), Tzuo (2007) state that children's playing freely and making individual choices in the learning centers are the basis of the child centered education. They also fore front the fact that these centers provide unique game opportunities that improve their creative skills, social skills and taking responsibility of their own learning (cited in Wood, 2014). A number of studies mention that well-designed classroom environment and physical setting have profound effects on children's cognitive development (Burchinal, Piesner-Feinberg, Bryant, Clifford, 2000; Ceglowski \& Bacigalupa, 2002; Burchinal \& Cryer, 2003; Feyman, 2006; Maxwell, 2007; Scraf, Eisenberg, Deater-Deckard, 1994), on social-emotional and language development (Burchinal, PiesnerFeinberg, Bryant, Clifford, 2000; Hewes, 2014). While Coughlin et al. (1997) state that well-designed class atmosphere supports teacher's instruction and is supportive in children's independence, being social and in solving the problems they encounter, Anders et al. (2012) and Mashburn (2008) claim that it is also effective on children's academic skills especially reading and Berris and Miller (2011) writing and contribute to children's all development parts. Moreover, learning centers are claimed to be places that help children make use of their own inner strategies such as individual interest and learning styles, increasing personal skills, experiential learning as a result of children's active participation (Day, 2007). The researches in Turkey about the physical environment, that is essential with respect to education quality, focus on specific areas in early childhood education. The studies are about teachers' opinions regarding physical environment (Çakır, 2011; Durmuşoğlu, 2008; Erşan, 2011; Ünüvar, 2011), evaluation of physical environment and examınation of quality (Biçer, 1994; Göl-Güven, 2009; Güleş and Erişen, 2013; Kalkan \& Akman, 2009; Karaküçük, 2008; Kubanç, 2014; Özgan, 2009; Tekmen, 2005; Yazıc1, Yellice \& Özer, 2003; Solak, 2007), the effects of physical environment on development (Feyman, 2006; Yalçın, 2011). The studies regarding learning centers are, problems lived in learning centers (Göl-Güven, 2009; Uçar, 2007), practices regarding free time activities (Ogelman, 2014; Özyürek and Aydoğan, 2011), use of science and natüre center (Parlakyıldız \& Aydoğan, 2004), qualification of book centers and (Deretarla-Gül \& Erden, 2003) specific and limited edition studies about creating learning centers (Özsırkıntı at al., 2014) are made.

For this reason, the study aims to determine the teachers' problems about learning centers and define teachers use and the teacher's design of learning centers. The study is important because it gives information about the teachers' opinions regarding learning centers, teacher's design of learning centers, teachers' role regarding the children effective use of learning centers, whether teachers use curriculum effective.

\section{METHOD}

\section{Research Design}

Present study aiming at investigating the situations of the learning centers and the applications regarding its use applied survey method. This is due to the need of examining the teachers' perceptions of learning centers and the applications of using these centers in its own setting as a whole (Büyüköztürk, 2013; Creswell, 2014; Yıldırım \& Şimşek, 2008).

\section{Participants}

In the study randomly selected teachers who were working in 6 independent pre-schools and 27 primary schools which had pre-schools in Aydin city center in 2014-15 academic year. The participants were selected on voluntary basis. 15 pre-school teachers (11 teachers from 27 schools with pre-schools and 5 teachers from independent pre-schools) participated in the study. All participants were female. The 
education level of participants is $81.8 \%$ were undergraduate graduates. The age of the participants are $60 \%$ of teachers were between $36-41$ years old and $40 \%$ were between 31-35.the time they work in the area are defined as, $31.3 \%$ had 16-20 year of experience, and 25\% had 11-15 year of experience.

Table 1. Demographic Characters of Working Group

\begin{tabular}{llrr}
\hline \multicolumn{2}{c}{ Demographic characters } & $\mathrm{n}$ & \multicolumn{1}{c}{$\%$} \\
\hline \multirow{2}{*}{ Sex } & Female & 15 & 100,0 \\
& Male & 0 & 0,0 \\
Age & $30-35$ & 5 & 33,3 \\
\multirow{3}{*}{ School type of graduation } & $36-45$ & 10 & 66,7 \\
\multirow{3}{*}{ School Type } & Degree & 13 & 86,7 \\
& Associate degree & 2 & 13,3 \\
& Preschool & 6 & 40,0 \\
\multirow{2}{*}{ Occupational seniority } & Kindergarten & 9 & 60,0 \\
& 5-10 years & 5 & 33,3 \\
& 11-15years & 3 & 20,0 \\
& 16-20 years & 3 & 20,0 \\
& 25 years & 4 & 26,7 \\
\hline
\end{tabular}

\section{Data Collection Tools}

Data were gathered through structured observation and interview. Structured observation is observing the previously identified situations in an education setting following a pre-prepared form (Ekiz, 2003). In order to prepare the observation, form the literature was reviewed, the facts regarding learning centers of early childhood education program that is revised in 2013 by Ministry of Education (Directorate General of Basic Education) is considered and the preschool classes are observed. The issues identified in the updated pre-school education program related to learning centers were taken into consideration, the classrooms in pre-school education centers were analyzed and the teachers' ideas were asked. The form was prepared with two sections which are related to designing and using learning centers. The observation form was assigned to two child development, two pre-school teacher education academics and three pre-school teachers for scrutiny. In order to see the applicability of the items that were revised according to expert opinions, pilot observations were done and the form was finalized.

In the first section of the learning centers observation form, there are 19 items in total; 11 items about "design of the centers" and 8 items regarding "using these centers. Three-Likert scale was used in the form; yes, no, to some extent. Next to each item a column was given for additional explanation about the observed situation. Teacher's Interview Form, on the other hand, consists of 12 questions six of which are about the general information of the class and the teacher and other six are about teachers' ideas of learning centers. In addition, a separate "Demographic Information Form" about the participating teachers and classes was used. In this form, five questions were asked regarding teachers' age, gender, experience, the child number that is found in the graduating classes and the size of the classes.

\section{Data Collection Procedure}

Having received the necessary allowance from Aydin National Education Directorate, schools where the classes would be observed were visited. One voluntarily participated teacher and her class were identified. Teachers and the administration were informed about the objective of the study and the form was filled by the teachers. Later on, in every class, the situations in the designing of the centers part of the form were filled in while observing the materials and the class. The part about the use of learning centers was filled in during observations done in three different days. Observations were done between the time children arrive school and the time when free game ends. Observations done in three days were recorded in different forms and a common score was reached after analyzing the forms of those three days.

\section{Data Analysis}

In the study for which descriptive and content analysis methods were used, pre-identified themes were used. The theme "designing learning centers" was explained with two sub-themes which are "physical conditions of learning centers" and "materials in learning centers". On the other hand, the theme "using 
learning centers" was explained through three sub-themes; "having children in learning centers", "children's benefitting from learning centers", "teacher's observing children in learning centers". Teachers' proficiency to design and use learning centers was tried to find out through content analysis (Yıldırım \& Şimşek, 2008, p. 256, 258).

\section{FINDINGS}

Codes were given to participating teachers due to confidentiality. Teachers were coded as "T" and every teacher was assigned a number.

\section{Teacher opinions about learning centers}

The teachers (that are participants of the study) determine that the number of students they worked in are12-23 (33,3\% 10-15 children, 33,3\% 16-20 and 33,3\% 21-25 children) and the classroom size is between $20-50 \mathrm{~m}^{2}$. All teachers attended to in-service teacher education program on 2013 pre-school education program.

Table 2. Teachers Opinions Regarding Learning Centers

\begin{tabular}{|c|c|c|}
\hline Interview questions & Teachers opinions & Teacher \\
\hline \multirow{3}{*}{$\begin{array}{l}\text { Self-sufficient status in } \\
\text { the regulation of } \\
\text { learning centers }\end{array}$} & Always & $\mathrm{T} 2, \mathrm{~T} 14$ \\
\hline & Almost & Т1, Т3, Т7, Т9, Т10, Т11, \\
\hline & Sometimes & T4, T6, T8 \\
\hline \multirow{3}{*}{$\begin{array}{l}\text { Self-sufficient status in } \\
\text { the use of learning } \\
\text { centers }\end{array}$} & Always & $\mathrm{T} 8$ \\
\hline & Almost & T3, T4, T6 \\
\hline & Sometimes & $\begin{array}{l}\text { T2, T5, T7, T9, T10, T11, } \\
\text { T12, T13, T14, T15 }\end{array}$ \\
\hline \multirow{3}{*}{$\begin{array}{l}\text { Regulation of learning } \\
\text { centers regarding } 2013 \\
\text { program principles. }\end{array}$} & Edited & T6, T10, T13, T14 \\
\hline & Not edited & T2, T5, T7 \\
\hline & Edited but then turn into old. & $\begin{array}{l}\text { T1, T3, T4, T8, T9, T11, } \\
\text { T12, T15 }\end{array}$ \\
\hline \multirow{8}{*}{$\begin{array}{l}\text { Reasons not to edit the } \\
\text { learning centers }\end{array}$} & Classroom size is too small & T1, T2, T5, T7, T9, T15 \\
\hline & The number of children is huge & T2, T3, T12 \\
\hline & $\begin{array}{l}\text { Materials such as cupboard or shelves are not } \\
\text { appropriate }\end{array}$ & $\begin{array}{l}\text { T2, T3, T4, T5, T7, T8, } \\
\text { T11, T15 }\end{array}$ \\
\hline & Class in set & $\mathrm{T} 1$ \\
\hline & $\begin{array}{l}\text { Limit the activity area as the play area or art } \\
\text { area }\end{array}$ & T3, T9, Т11, T12 \\
\hline & Be certain agglomeration centers & $\mathrm{T} 4, \mathrm{~T} 11$ \\
\hline & Because other teachers do not want & T5, T8 \\
\hline & I do not think it is appropriate & $\mathrm{T} 1, \mathrm{~T} 7$ \\
\hline \multirow{7}{*}{$\begin{array}{l}\text { Problems in learning } \\
\text { centers }\end{array}$} & Do not have problems & T1, T7, T11, T14, T15 \\
\hline & Huge children in certain centers & T2, T5, T6, T12 \\
\hline & $\begin{array}{l}\text { Have discussion due to the problems such as } \\
\text { Noise, discussion, lack of materials; disturb } \\
\text { each other, and sharing. }\end{array}$ & T2, Т3, T4, T6, T7, T8, T9 \\
\hline & $\begin{array}{l}\text { The children in the center is unable to move } \\
\text { freely }\end{array}$ & T9 \\
\hline & In sufficient materials & T6, T13 \\
\hline & The class is very narrowing. & T5, T10 \\
\hline & $\begin{array}{l}\text { I can't help with the transitions between the } \\
\text { centers }\end{array}$ & T10, T13 \\
\hline
\end{tabular}

With regards to teachers' proficiency about learning centers, three teachers (T2, T5, and T14) "always", nine teachers "often", and three teachers (T4, T6, T8) sometimes felt proficient in designing learning centers. In relation to the use of those centers, only one teacher (T8) "always", ten teachers "often", and four teachers (T1, T3, T4, T6) “sometimes” felt proficient. Four teachers (T6, T10, T13, and T14) stated they did design the centers according to the 2013 program, whereas three teachers (T2, T5, T7) stated they did not design according to this program. Other eight teachers, on the other hand, declared that they 
did design however, because of the problems faced during application; they moved the divisions and used the centers as they were previously. Teachers who did not design or changed the design they did explained the reasons as; "small size of the classroom", "the excessive number of students", "placing children in some parts that cause chaos and discipline problems", "not having suitable furniture in the classroom", "centers divided into sections limit students' freedom". T9 inclined that she could not solve the problems in application with the following words "I was very willing right after the training; however, I could not apply anything because of the small size of the classroom."

The participants stated the problems in learning centers as "I don't live problems (T1, T7, T11, T14, $\mathrm{T} 15)$, Clutter happens in certain corners (T1, T7, T11, T14, T15), have discussions regarding noise, discussion, material failure, disturb each other, share (T2, T3, T4, T6, T7, T8, T9, children don't move easily in the centers (T9), insufficient material (T6, T13), narrowing class (T5, T10), cannot stop the transition between centers (T10, T13)”

\section{Findings related to designing learning centers}

\section{A. Observation situations regarding physical arrangement}

Table 3. Observation Situations Regarding Learning Centers Design

\begin{tabular}{|c|c|c|c|c|}
\hline Observation situations & Yes & No & Some times & Notes \\
\hline $\begin{array}{l}\text { The number of learning } \\
\text { center is determined } \\
\text { regarding the classroom } \\
\text { size. }\end{array}$ & - & $\begin{array}{l}\text { T1, T2, T3, } \\
\text { T4, T5, T6, } \\
\text { T7, T8, T9, } \\
\text { T10, T11, } \\
\text { T12, T13, T15 }\end{array}$ & $\mathrm{T} 14$ & $\begin{array}{l}\text { All class has all learning centers but the } \\
\text { classroom size is not considered. }\end{array}$ \\
\hline $\begin{array}{l}\text { The width of learning } \\
\text { centers is determined } \\
\text { regarding classroom size. }\end{array}$ & - & $\begin{array}{l}\text { T1, T2, T3, } \\
\text { T4, T5, T6, } \\
\text { T7, T8, T9, } \\
\text { T10, T11, } \\
\text { T12, T13, } \\
\text { T14, T15 }\end{array}$ & - & $\begin{array}{l}\text { Because the learning centers are not } \\
\text { designed according to the classroom } \\
\text { size, most of the class has the materials } \\
\text { of science center, music center, and } \\
\text { book center in the cupboard, and the } \\
\text { children activity areas are limited. }\end{array}$ \\
\hline $\begin{array}{l}\text { The learning centers are } \\
\text { designed according to the } \\
\text { feature (light, being } \\
\text { loud/quiet). }\end{array}$ & $\begin{array}{l}\text { T6, T13, } \\
\text { T14 }\end{array}$ & $\begin{array}{l}\text { T2, T4, T5, } \\
\text { T7, T10 }\end{array}$ & $\begin{array}{l}\text { T1, T3, T8, T9, T11, } \\
\text { T12, T15 }\end{array}$ & \\
\hline $\begin{array}{l}\text { Learning centers are } \\
\text { defined from each other. }\end{array}$ & $\frac{\mathrm{T} 6, \mathrm{~T} 13}{\mathrm{~T} 14}$ & - & $\begin{array}{l}\text { T1, T2, T3, T4T5, T7, } \\
\text { T8, T9, T10, T11, } \\
\text { T12. T15 }\end{array}$ & $\begin{array}{l}\text { The learning centers are separated but } \\
\text { the limitations are not defined. }\end{array}$ \\
\hline $\begin{array}{l}\text { The materials in the } \\
\text { learning centers give } \\
\text { opportunity to the children } \\
\text { to see the other centers } \\
\text { and the other children.. }\end{array}$ & & & $\begin{array}{l}\text { T1, 2, T4, T5, T6, T7. } \\
\text { T8T9, T10, T11, T12, } \\
\text { T13, T14, T15 }\end{array}$ & $\begin{array}{l}\text { Most of the cupboards that, has the } \\
\text { materials in all classes are higher than } \\
\text { the children reach ability and the } \\
\text { cupboards has the covers. } \\
\text {. }\end{array}$ \\
\hline $\begin{array}{l}\text { The children can reach the } \\
\text { materials in the learning } \\
\text { centers easily. }\end{array}$ & $\begin{array}{l}\text { T1, T2, } \\
\text { T3, T4, } \\
\text { T5, T7, } \\
\text { T8, 9, } \\
\text { T11, T1, } \\
\text { T2, T15 }\end{array}$ & - & T6, T10, T13, T14 & $\begin{array}{l}\text { The children sight and reach ability are } \\
\text { limited by the cupboards height and the } \\
\text { front and back cupboards covers in } \\
\text { most of the classes. }\end{array}$ \\
\hline $\begin{array}{l}\text { The name of learning } \\
\text { centers are clarified by } \\
\text { visual materials. }\end{array}$ & - & - & $\begin{array}{l}\text { T1, T2, T3, T4, T5, } \\
\text { T6, T7, T8, T9, T10, } \\
\text { T11, T12, T13, } \underline{\text { T14. }} \\
\underline{\text { T15 }}\end{array}$ & $\begin{array}{l}\text { The pictures are used in all classes as } \\
\text { visual materials, the pictures are remote } \\
\text { for children sight, They are small and } \\
\text { in attractive and the pictures in most of } \\
\text { the classes are wrinkled edges and torn. }\end{array}$ \\
\hline
\end{tabular}

According to the table in 3; the observations of the number and size of learning centers revealed that, all teachers gave place to dramatic play center, block center, music center, science center, puppet center, and library center. Only one teacher (T14) gave place to art center in their classes. In the classes where there was no art center, students were observed to draw and do drawing at a table with their drawing materials as the art activity. While designing learning centers, regardless of the size of the classes, big (31-50 $\left.\mathrm{m}^{2}\right)$ and small $\left(20-30 \mathrm{~m}^{2}\right)$, teachers placed all centers. In small classes $(\mathrm{N}=9)$, teachers were observed not to combine some centers. This situation narrowed the places of the centers, especially 
science, library and music centers were observed to include only a cup boarder the materials stuck on the walls. There was not adequate place for children to do any activities in these centers. Physical conditions of the classes and the size of the centers were not paid attention in any classroom. Places left for dramatic game and block centers were more compared to other centers which narrowed others' places. Centers were not preferred to be combined in any classroom.

In relation to the characteristics of the learning centers (noisy/quiet, getting light etc.), three teachers (T6, T13, T14) were observed to do arrangement, and five teachers (T2, T4, T5, T7, T10) were observed to ignore this situation. Separation of learning centers (with shelves, cupboards, carpets etc.) were done by only three teachers (T6, T13, T14), other 13 teachers did arrangement to some extent. In classes where arrangement was done to some extent, separation was tried to be done with cupboards placed to four walls of the classroom or carpets, tables and other materials placed in some centers. This arrangement, however, could not reveal the borders of centers adequately. Moreover, the necessary arrangements to enable students see other centers and their friends in other centers were not done properly in any classroom. Some of the cupboards were above the eye level of the children and they did not have open shelf system decreased the communication by preventing them from seeing their friends in different centers. Open shelf system was only in one classroom, in other classes some cupboards did have covers, some of their fronts were open but backs were closed. Accessing materials in the centers were limited due to the characteristics of the cupboards. To illustrate, some students could not reach the materials themselves, either the teacher gives them or leave the materials on the tables. Materials in the covered cupboards failed to distract students and they were not used.

\section{B. Observation findings about sub-theme of materials}

Table 4. Observation Findings Regarding Material Features in the Learning Centers

\begin{tabular}{|c|c|c|c|c|}
\hline Observations & Yes & No & Sometimes & Notes \\
\hline $\begin{array}{l}\text { Different materials } \\
\text { are found in } \\
\text { learning centers. }\end{array}$ & - & $\begin{array}{l}\text { T1, T2, T3, } \\
\text { T4, T5, T6, } \\
\text { T7, T8, T9, } \\
\text { T10, T11, } \\
\text { T12, T13, } \\
\text { T15 }\end{array}$ & T14 & $\begin{array}{l}\text { Only one class has different materials in } \\
\text { different learning centers; in music } \\
\text { center (keyboards, drums), science } \\
\text { center( Stones, feather, Shell), and art } \\
\text { center(easel, different materials, pictures } \\
\text { of various artists) }\end{array}$ \\
\hline $\begin{array}{l}\text { There are sufficient } \\
\text { materials in learning } \\
\text { centers. }\end{array}$ & $\begin{array}{l}\text { T1, T2, T3, } \\
\text { T4T5, T6, } \\
\text { T7, T8, T9, } \\
\text { T10, T11, } \\
\text { T12, T13, } \\
\text { T15 }\end{array}$ & & & $\begin{array}{l}\text { The materials in all classes are in } \\
\text { sufficient in terms of quality and } \\
\text { quantity. }\end{array}$ \\
\hline $\begin{array}{l}\text { The additions } \\
\text { according to the } \\
\text { acquisition and } \\
\text { indicators are made } \\
\text { in learning centers. }\end{array}$ & - & $\begin{array}{l}\text { T1, T2, T3, } \\
\text { T4T5, T6, } \\
\text { T7, T8, T9, } \\
\text { T10, T11, } \\
\text { T12, T13, } \\
\text { T15 }\end{array}$ & T14 & $\begin{array}{l}\text { In one class, that is partially provided, } \\
\text { teacher add the eggs in the science } \\
\text { center (the teacher stated that they } \\
\text { focused on the concept of solid and } \\
\text { liquid in that day). }\end{array}$ \\
\hline $\begin{array}{l}\text { The learning centers } \\
\text { that are less } \\
\text { preferred, has been } \\
\text { made more } \\
\text { attractive. }\end{array}$ & $\begin{array}{l}\text { T4, T10, } \\
\text { T14 }\end{array}$ & $\begin{array}{l}\text { T1, T2, T3, } \\
\text { T5, T6, T7, } \\
\text { T8, T9, T11, } \\
\text { T12, T13, } \\
\text { T15 }\end{array}$ & & $\begin{array}{l}\text { Most of the classes has functional book, } \\
\text { science and music center but they are not } \\
\text { attractive for children. }\end{array}$ \\
\hline
\end{tabular}

As determined in table 4 in only one classroom that was observed, the teacher (T14) placed various materials in learning centers (organ and drums in music center, stones, feather, sea shells, tree branches in science center, drawing table in art center, different materials and reproductions of famous artists). In other teachers' classrooms similar materials (toys and kitchen tools in home center, colorful blocks in block center, and similar story books in library center) were placed. Not all centers included adequate amount of materials. The most materials were in block, dramatic game and library center. However, these materials were not enough in terms of quality despite being adequate quantitatively. 
Only one teacher (T14) adds new materials to the learning centers according to the aims and goals, regarding observations that are made in 3 different times. The teacher adds eggs to the science center for children discover. Exclude 3 teachers. (T4, T10, T14), the other teachers do not make any arrangements that could capture the children interest in the less preferred (especially books, science, music) centers. Because the 3 days observation time is limited for generalization, it is not known whether the teachers add materials in other times.

\section{Observation findings about the use of learning centers}

\section{Sub-theme observation findings about having children in the centers}

According to Table 5, when the children's placing was paid attention, only one teacher (T14) was observed to guide children in their center selection. T14 talked to the students about in which center they would work and asked their opinion while starting the day. In other 14 classrooms, students went to any center they wanted. In none of the classrooms, rules regarding how many students would be placed in which center were identified and arrangements were done. When many students select one center, T14 guides students by saying "you worked there before” or "you need to choose another center". However, in other classrooms children were mostly grouped in dramatic game or block center. As a result of the number of students in these centers, sometimes children were observed to argue or take the basket and move to another place in the room. Except these two centers, other centers were observed not to be used in line with their purposes. And those centers transformed to be places where children play other games.

Table 5. Observation Findings about Having Children in the Learning Centers

\begin{tabular}{|c|c|c|c|c|}
\hline Observation situations & Yes & No & Sometimes & Notes \\
\hline $\begin{array}{l}\text { For the settlement of } \\
\text { children in the learning } \\
\text { center, an appropriate } \\
\text { method is used }\end{array}$ & T14 & $\begin{array}{l}\text { T1, T2, T3, } \\
\text { T4T5, T6, T7, } \\
\text { T8 T9, T10, } \\
\text { T11, T12, T13, } \\
\text { T15 }\end{array}$ & - & $\begin{array}{l}\text { Only one teacher, asked children to } \\
\text { select their work in center, in the } \\
\text { circle time. }\end{array}$ \\
\hline $\begin{array}{l}\text { It is determined that, } \\
\text { how many children will } \\
\text { be found in each } \\
\text { learning center. }\end{array}$ & - & $\begin{array}{l}\text { T1, T2, T3, T4, } \\
\text { T5T6, T7, T8, } \\
\text { T9, T10, T11, } \\
\text { T12, T13, T15 }\end{array}$ & $\mathrm{T} 14$ & $\begin{array}{l}\text { There are accumulations in the } \\
\text { dramatic play area and block center. } \\
\text { Only one teacher limited the children } \\
\text { numbers in learning centers by saying } \\
\text { "You play in that learning center } \\
\text { yesterday, if you want you can play } \\
\text { in other learning center". }\end{array}$ \\
\hline $\begin{array}{l}\text { There are children in all } \\
\text { learning centers within } \\
\text { days. . }\end{array}$ & T14 & $\begin{array}{l}\text { T1, T2, T3, T4, } \\
\text { T5, T8, T9, T11, } \\
\text { T12, T13, T15 }\end{array}$ & $\begin{array}{l}\text { T6, T10, } \\
\text { T13 }\end{array}$ & $\begin{array}{l}\text { Almost all classes, children and out } \\
\text { of the all learning centers.. }\end{array}$ \\
\hline $\begin{array}{l}\text { Rules that must be } \\
\text { followed when working } \\
\text { in learning centers was } \\
\text { defined and supported } \\
\text { with visuals. }\end{array}$ & - & $\begin{array}{l}\text { T1, T2, T3, T4, } \\
\text { T5T6, T7, T8, } \\
\text { T9, T10, T11, } \\
\text { T12, T13, T14, } \\
\text { T15 }\end{array}$ & - & $\begin{array}{l}\text { There is a predetermined } \\
\text { arrangement. Teachers stimulate } \\
\text { children to obey the rules and often } \\
\text { warns their children about what they } \\
\text { can do. }\end{array}$ \\
\hline
\end{tabular}

Only one teacher (T14) managed to have children in all centers, three teachers (T6, T10, T13) managed to some extent and in some centers of 11 teachers' classes were observed not to have any children during the day. All centers were preferred by all children in T14's classroom and she prevented to have all children in only one center. As it was the case in other classrooms, children were observed not to be in only dramatic play and block centers. They were not also insistent to play in these centers. The rules that children should obey while playing in the centers were not set in any of the classrooms. Teachers were confined to warn the children frequently when they disturb or distract each other, or to ask them tidy the centers.

Findings about the children's benefitting from the centers sub-theme

According to Table 6 none of the teachers were observed to make children benefit from the learning centers. During the observations done on three different days, teachers were observed not to do anything 
regarding children's choice of learning centers, whether they played in the same center the previous day or not, or whether children were making use of different centers. Only children in one teacher's classroom (T14) were benefitting from the less preferred centers (e.g. science, music, and library) by the help of the arrangement and the guidance of the teacher. In other classrooms, children were staying in these centers for a very short time without doing any activities.

Table 6. Observation Findings about Children Use of Learning Centers

\begin{tabular}{|c|c|c|c|c|}
\hline Observation findings & Yes & No & Sometimes & Notes \\
\hline $\begin{array}{l}\text { Children benefits from } \\
\text { all learning centers. }\end{array}$ & - & $\begin{array}{l}\text { T1, T2, T3, T4, } \\
\text { T5, T6, T7, T8, } \\
\text { T9, T10, T11, } \\
\text { T12, T13, T14, } \\
\text { T15 }\end{array}$ & 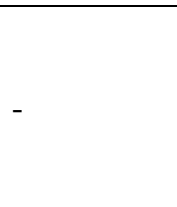 & $\begin{array}{l}\text { In } 3 \text { days observations, it is observed } \\
\text { that, there is no routing for children } \\
\text { to select different learning centers }\end{array}$ \\
\hline $\begin{array}{l}\text { It is supported that; } \\
\text { children have peer } \\
\text { interaction with } \\
\text { different peers. }\end{array}$ & & $\begin{array}{l}\text { T1, T2, T3, T4, } \\
\text { T5, T6, T7, T8, } \\
\text { T9, T10, T11, } \\
\text { T12, T13, T15 }\end{array}$ & T14 & $\begin{array}{l}\text { There have been no attempts to } \\
\text { control and edit this situation by the } \\
\text { teachers. }\end{array}$ \\
\hline $\begin{array}{l}\text { Children start their } \\
\text { activity at the center } \\
\text { they chose and continue } \\
\text { for a certain time. }\end{array}$ & T14 & $\begin{array}{l}\text { T1, T2, T3, T4, } \\
\text { T5, T6, T7, T8, } \\
\text { T9, T10, T11, } \\
\text { T12, T13, T15 }\end{array}$ & - & $\begin{array}{l}\text { In all classes except one class, } \\
\text { children always change the activity } \\
\text { and the learning center; they don’t } \\
\text { start and continue an activity or play } \\
\text { for a while. }\end{array}$ \\
\hline
\end{tabular}

Children only in one classroom (T14) were observed to continue the game that they started in the centers they chose. In other 14 classrooms children were frequently changing the center and the game instead of continuing. Children were observed to have attention problems because of the distracters around, and as a result, there was a continuous chaos in those classrooms. In such a situation, teachers were continuously warning children to be quiet, children were complaining about their friends who are not on task. And all these situations caused discipline problems.

Only one teacher (T14) to some extent made the children to be in contact with different mates in learning centers. Thanks to the teacher's (T14) guiding the children to other centers when the specific centers were full, children had the chance to play with other children. Other participating teachers were observed not to have any applications to control or make children play with different mates, so children played with their besties.

\section{Findings about teachers' observing children sub-theme}

Table 7. Findings about the Teachers Observations on Children in the Learning Center

\begin{tabular}{|c|c|c|c|c|}
\hline Observation Findings & Yes & No & Sometimes & Notes \\
\hline $\begin{array}{l}\text { Teacher observes the } \\
\text { children during the } \\
\text { activity in the learning } \\
\text { center. }\end{array}$ & T14 & $\begin{array}{l}\text { T1, T2, T3, T4, } \\
\text { T5, T6, T7, T8, } \\
\text { T9, T10, T11, T12, } \\
\text { T13, T14, T15 }\end{array}$ & - & $\begin{array}{l}\text { All teachers except one, is busy with } \\
\text { other works (such as preparation for } \\
\text { the next activity, check the children's } \\
\text { homework). }\end{array}$ \\
\hline
\end{tabular}

According to Table 7, while the children were studying in the learning centers, only one teacher (T14) observed the children. T14 were observing the students during their activities and sometimes she attended the activities herself. In other classrooms, teachers were checking the assignments of the students, getting prepared for the next activity or dealing with their own routine works while the children were playing in the centers. Teachers were orally warning the students when a problem occurred.

\section{DISCUSSION and CONCLUSIONS}

Participating teachers perceived themselves competent enough in designing and using the learning centers. All participants stated that they attended the INSET training about 2013 program, designed the learning centers accordingly and cancelled the arrangements due to some practical problems. Even though the problems posed by the teacher could be solved by the help of the 2013 program principles and the literature, they showed that teachers did not have enough knowledge regarding the purpose of 
the learning centers, how to design and make use of them. Yazic1 et al. (2003) also put forth that there is a significant difference between the observation results and the evaluations of the teachers and the administrators. This study showed that although the teachers perceived themselves informative enough to design and use the learning centers, they are not competent in application as was stated by Dere (2001). In Dere's study, teachers were also observed not to put enough effort in creating centers and using the materials in the classrooms.

Observation results regarding the arrangement of the learning centers showed that most of the teachers are incompetent. Çetinkaya (2010) and Ural and Ramazan (2007) mentioned that classrooms are very small in comparison with the number of the students. Biçer (1994), Gürpınar (2006) and Özyürek and Aydoğan (2011) stated that teachers tried to give place to all interest corners. Despite the suggestions such as two-center classroom arrangement (MEB, 2013) or planning the centers in turn to make the students benefit from each center (Kandır, 2001), teachers' belief about creating every center narrowed the space of the centers. Erşan (2011) also stated that teachers perceive art activities as tasks that are done under their control and thought that it is not necessary to create a center for art.

Many studies showed the significance of the classrooms where the borders of learning centers are clear. Caples (1996) stated that a large classroom in which the borders of learning centers are identified comforted the children by preventing the stress that large classrooms cause on students. West (2011) found that children focused on materials easier. Bullard (2009) and Akçay (2011) put forth that children use the materials easily, work independently. Moreover, Greenman (2007) inclined that this would help improvement in children's self-control and evaluation. Tezel (1999), in addition, mentioned that learning centers with borders meet the privacy needs of children. While Şahin, Sak, Sak and Tuncer (2013) found that teachers believe in the negative effect of physical conditions on class management, Özsırkıntı, Akay and Yılmaz-Bolat (2014) found that more than half of the teachers (54\%) believe in the positive effect of the centers with clear borders. However, findings showed that teachers are mostly incompetent in using learning centers efficiently. And even though the centers were divided with borders, they were observed not to have adequate teaching strategies.

Physical arrangements help children decrease being dependent on an adult and improve the feelings of safety and control by providing children with opportunities to use the materials themselves, be in contact with others, be accessible and visible (Güleş, 2013; Mills, 1998; Sanoff, 1995). De Carvalho (2004), in his study where he made use of three different places (structured, semi-structured, unstructured) found that children in structured classroom (classroom divided into parts with cupboards, furniture) had less communication with adults and preferred to have more communication with friends. Findings of this study demonstrated that when the cupboards are high and covered caused difficulty in seeing other centers and children. While Güleş (2013) found that teachers thought that materials should be accessed easily, Erşan (2011), Ural and Ramazan (2007), and Çetinkaya (2010) and this study's found that teachers do not prefer children to reach the materials easily.

In the light of the fact that learning centers contribute to the self-learning of the children to a great extent, every teacher should provide opportunities to children in line with their needs and the interest by reviewing the learning centers regarding materials and activities (Dicarlo \& Vagianos, 2009; Stephens, 1996). The fact that learning centers that are paid less attention should be made attractive by the teachers was mentioned both in the literature and the 2013 program (Beaty, 2013; Diffily et al., 2001; MEB, 2013; Prevost, 2013). Erşan (2011) found that teachers did not do any adjustment and they kept the same materials for weeks. Even though the study by Özsırkıntı et al., (2014) put forth that most of the teachers were for the idea that teachers can design the centers on daily basis, many studies (Ayvac1, Devecioğlu \& Yiğit, 2010; Çetinkaya, 2010; Deretarla et al, 2003; Parlakyıldız \& Aydın, 2004; Özgan, 2009; Uçar, 2007; Ural \& Ramazan, 2007) support the idea that teachers are in competent in this field.

Findings regarding the use of learning centers revealed that there are no rules regarding choosing learning centers, number of students in each center, using learning centers. Chaos is prevented and children's benefitting from each center is provided by using external instruments about how many children will use which center (Beaty, 2013; Diffily et al. 2001; Güler, 2007; Kocamanoğlu, 2014; West, 2011). These arrangements also improve children's skills of self-arrangement, and understanding and accepting others' needs (Beaty, 2013; Diffily et al. 2001). Moreover, Diffily et al. (2001) stated that children spend more time on activities that they chose, and Güler (2007) pointed out those children's motivation and attention span increase. As it is the case in this study, Ogelman (2014) also found that teachers did not talk to the students about which center to choose. Most of the students (53.5\%) started 
an activity in a center they wanted. Demiriz, Karadağ and Ulutaş (2003) stated that the number of students that would use the centers actively would be identified by taking the amount of materials, size of the classroom and the output into consideration. The findings of Çetinkaya (2010), and Ural and Ramazan (2007) about small size of the inner space, insufficiency of the materials, teachers' not having the awareness of designing the class for education purposes, support the findings of this study.

Findings about children's benefitting from learning centers showed that the levels of children regarding benefitting from all centers, being in contact with friends, starting and continuing an activity they chose in a center are very low. Sanoff (1995) mentions the importance of a learning center's providing the children with the opportunity to start continue and finish an activity. West (2011) states that learning centers divided with borders help children reach the materials easier and Butin (2000) claims that they prevent being disturbed during the activity improve communication among students and increase the invention skills of children. Similarly, Olds (1989) stated that negative behavior of children increased and Nash (1981) indicated that children's creativity improved. They were observed to produce more colors and shapes. However, the insufficiency regarding the use of learning centers decreases the children's benefitting from these centers.

Another important finding about learning centers is that nearly none of the teachers were observing the students. Ogelman (2014) also indicated that teachers were dealing with other things or spending their time out of the classroom instead of observing children during free time activities. Learning centers are places for activities during which children are active, creative and experiencing. That's why the experiences children gain in those centers help teachers learn about children. However, the findings of this study showed that teachers are doing their daily routine works instead of observing children.

This study, which was conducted to investigate the applications in learning centers, revealed that despite feeling competent in designing and using learning centers, teachers were not informative and skillful enough. Limited number of studies conducted with the same purpose demonstrated that there is some insufficiency due to some reasons about teachers' designing and using these centers. In the light of this fact teachers can be suggested; to design and use these centers effectively according to their purpose, significance, to observe children during the activities, to increase their skills about increasing communication among children, between themselves and children.

\section{Implications}

Researchers in this field can be suggested; to create an awareness regarding the design and use of learning centers by conducting experimental studies about the impact of effective use of learning centers on children's development and learning, to conduct longitudinal studies about how to maintain effective student-teacher communication during the games in learning centers.

Ministry of National Education is also suggested; to plan more intensive and continuous practical and theoretical INSET programs to support teachers, to have an efficient cooperation between the Educational Tools and Publications Office and private institutions to produce high quality materials that should be present in preschools with a disciplined perspective.

\section{REFERENCES}

Anders, Y., Rossbach, H. G., Weinert, S., Ebert, S., Kuger, S., Lehrl, S., \& Von Maurice, J. (2012). Home and preschool learning environments and their relations to the development of early numeracy skills. Early Childhood Research Quarterly 27, 231- 244

Anonymous, (2010). Preparing Children for Kindergarten. Indiana Institute Disability and Community. Indiana University.

Ayvac1, H.Ş., Devecioğlu,Y. \& Yiğit, N. (2002). Okulöncesi Öğretmenlerinin Fen ve Doğa Etkinliklerindeki Yeterliliklerinin Belirlenmesi. Taken from http://wwwJedu.metu.edu.tr/utbmek 5/b_kitabl/PDF/ogretmen yetiştirme /bildiri/t277.pdf. (2).

Beaty, J. (2013). Preschool appropriate practices: environment curriculum and development. Australia: Wadsworth Cengage Learning,

Berris, R \& Miller, E. (2011). How design of the physical environment impacts early learning: educators and parents’ perspectives. Australasian Journal of Early Childhood, 36(4).1-17.

Biçer, M. (1994). Ankara il merkezindeki anasınıfları ile uygulama anaokullarının fiziki özellikler açısından klyaslanarak değerlendirilmesi. Published mater thesis. Gazi University, Social Sciences Institute, Ankara.

Bullard, J. (2009). Creating environments for learning: birth to age eight. Enhanced Pearson e-text, New Jersey: Merrill. 
Burchinal, M., \& Cryer, D. (2003). Diversity, child care quality, and developmental outcomes. Early Childhood Research Quarterly, 18(4); 401-426.

Burchinal, M., Peisner-Feinberg, E., Bryant, D., \& Clifford, R. (2000). Children's social and cognitive development and child-care quality: testing for differentials societies related to poverty, gender, or ethnicity. Applied Developmental Science, 4(3), 149-165.

Butin, D. (2000). Early childhood centers. clearing house for educational facilities. Washington, D.C. Department of Education, Washington, DC.2000-07-00 ERIC ED 446422.

Büyüköztürk, Ş. (2013). Bilimsel araştırma yöntemleri. Ankara, Türkiye. Pegem Akademi.

Ceglowski, D., \& Bacigalupa, C. (2002). Four perspectives on child care quality. Early Childhood Education Journal, 30(2), 87-92.

Caples, S. E. (1996). Some guidelines for preschool design. Young Children, 51(4), 14-21.

Coughlin, P. A., Hansen, K. A., Heller, D., Kaufmann, R. K., Stolberg, J. R., \& Walsh, K. B. (1997). Creating Child-Centered Class-Rooms. Washington, DC: Children's Resources International, Inc.

Creswell, J.W. (2014). Nitel araştırma yöntemleri (beş yaklaşıma göre nitel araştırma ve araştırma deseni). İstanbul, Türkiye: Siyasal Akademi.

Çakır, A. (2011). Okul öncesinden ilgi köşelerinin düzenlenmesinin ve kullanılmasının öğretmen görüşlerine göre değerlendirilmesi. Yayımlanmamış yüksek lisans tezi, Çanakkale On Sekiz Mart Üniversitesi, Çanakkale.

Çetinkaya, B. (2010). Türkiye'de okul öncesi eğitim ve sorunlar (Bahçelievler ilçesi örneği). Unpublished maser thesis, Beykent Üniversitesi, İstanbul.

Day, C. (2007). Environment and children: Passive lessons from the everyday environment. Oxford: Elsevier Ltd.

Demiriz, S., Karadağ, A., \& Ulutaş, D. (2003). Okul öncesi eğitim kurumlarında eğitim ortamı ve donanımı. Ankara, Türkiye. Anı Yayıncılık.

Deretarla Gül, E. \& Erden, Ş., (2003). Anasınıfı öğretmenlerinin anadili etkinliklerinin ve kitap köşesinin niteliğini değerlendirmeleri. OMEP Dünya Konsey Toplantısı ve Konferansı Bildiri Kitabı. Cilt 3. ss:135-151.

Dicarlo, C.F., \& Vagianos, L., (2009). Using child preferences to increase play across interest centers in inclusive early childhood classrooms. Young Exceptional Children, Vol.12, 31-39

Diffily, D., Donaldson, E., \& Sassman, C. (2001). The scholastic book of early childhood learning center. New York, DC: Scholatic. İnc.

Durmuşoğlu, M.C. (2008). An examination of the opinions of preschool teachers about preschool learning settings in their schools. Eurasian Journal of Educational Research, 32, 39-54.

Erşan, Ş. (2011). Okul öncesi eğitim kurumlarında görev yapan ögretmenlerin ilgi köşelerinde serbest oyun etkinlikleri ile ilgili görüş ve uygulamalarının incelenmesi. Unpublished doctoral thesis, Gazi Üniversitesi, Educational Sciences Institute, Ankara,

Feyman, N. (2006). Okul öncesi ĕgitim kurumlarında kalitenin çocukların gelişim alanları üzerine etkisinin incelenmesi. Unpublished master thesis, Hacettepe Üniversitesi, Ankara.

Greenman, J. (2007). Caring spaces, learning places: children's environments that work. Redmond, WA: Exchange Press, Inc. [Electronic version]. Children's Environments Quarterly, 6(4), 8-16.

Gül Güven, M. (2009). Evaluation of the quality of early childhood classrooms in Turkey. Early Child Development and Care, 179(4), 437-451.

Güler, T. (2007). Erken çocukluk döneminde oyun planlama modeli. Eğitim ve Bilim Dergisi, 32 (143), 117-128

Güleş, F. (2013). Okul öncesi eğitimde fiziksel çevreye ilişkin kalite standartlarının belirlenmesi. Unpublished doctoral thesis, Selçuk Üniversitesi, Sosyal Bilimler Enstitüsü, Konya.

Güleş, F., \& Erişen, Y. (2013). Okul öncesi eğitimde fiziksel çevre standartlarını belirleme: paydaş görüşlerine dayalı bir analiz. Selçuk Üniversitesi Sosyal Bilimler Enstitüsü Dergisi, Vol: 30, 2013, pp. 129-138

Gürpınar, A. (2006). Okul öncesi ögrenimine devam eden çocukların tercih ettikleri ilgi köşeleri ve tercih etme nedenleri. Unpublished master thesis, Anadolu Üniversitesi, Eskişehir.

Hewes, J. (2014). Seeking Balance in Motion: The Role of Spontaneous Free Play in Promoting Social and Emotional Health in Early Childhood Care and Education. Children,1, 280-301; doi:10.3390.

Kalkan, E. \& Akman, B. (2009). Examining preschools quality in terms of physical conditions. Prodecia Social and Behavioral Sciences I, 1573-1577.

Kandır, A. (2001). Okul öncesi eğitim programlarında serbest zaman etkinliklerinin planlanması. gazi üniversitesi anaokulu/anasınıfı öğretmeni el kitabı. İstanbul, Türkiye: Ya-Pa Yayınları.

Karaküçük, S. A. (2008). Okul öncesi eğitim kurumlarında fiziksel/mekânsal koşulların incelenmesi: Sivas ili örneği. Çukurova Üniversitesi, Sosyal Bilimler Dergisi, (32):2, 307-320.

Kocamanoğlu, D.Ö. (2014). Öğrenme merkezleri kullanılarak oluşturulan bir okul öncesi ĕgitim sınıfinda çocukların sanat ürünlerinin incelenmesi and estetik yarglarının belirlenmesi. Published master thesis, Ankara Üniversitesi, Social Sciences Institute, Ankara.

Kubanç, Y. (2014). Okul öncesi eğitim kurumlarının fiziki durumunun incelenmesi. Journal of International Social Research .7(31),675-688. 
Mashburn, A. J. (2008). Quality of social and physical environments in preschools and children's development of academic, language, and literacy skills. Applied Developmental Science,12.3, 113-127, DOI:10.1080/10888690802199392

Maxwell, L.E. (2007). Competency in child care settings. the role of the physical environment. Environment and Behavior, 39(2),229-245, DOİ: 10.1177/0013916506289976

MEB, (2013). Okul Öncesi Eğitimi Genel Müdürlüğ̈̈ Okul Öncesi Eğitim Programı (36-72 Aylık Çocuklar Iç̧in) Kitabı. Ankara, Türkiye: Meb Yayınları.

Mills, R.P. (1998). Preschool planning guide building a foundation for development of language and literacy in the early years. The University of the State of New York the State Education Department, Albany, New York

Nash, B. C. (1981). The effects of classroom spatial organization on four and five years old children's learning. British Journal of Educational Psychology, 51(2);144-55.

Ogelmen, H.G. (2014). Okul öncesi eğitim kurumlarında serbest zaman etkinliklerinin gözlemlenmesi. Mustafa Kemal Üniversitesi Sosyal Bilimler Enstitüsü Dergisi, 11(26), 125-138.

Olds, A. R. (1989). Psychological and physiological harmony in child care center design. Children's Environments Quarterly, 6.4 (1989): 8-16.

Özgan, H. (2009). An evaluation related with preschool education in Turkey. World Applied Sciences Journal, 7(3),312-319.

Özsırkıntı, D., Akay, C., \& Yılmaz-Bolat, E. (2014). Okul öncesi öğretmenlerinin okul öncesi eğitim programı hakkındaki görüşleri (Adana ili örneği). Ahi Evran Üniversitesi Kırşehir Ĕ̌itim Fakültesi Dergisi (KEFAD), 15(1), 313-331

Özyürek, A., \& Aydoğan, Y. (2011). Okul öncesi öğretmenlerinin serbest zaman etkinliklerine ilişkin uygulamalarının incelenmesi. Sakarya Üniversitesi Eğitim Fakültesi Dergisi, 22, 41-58.

Parlakyıldız \& Aydın (2004), Okulöncesi dönem fen eğitiminde fen ve doğa köşesinin kullanımına yönelik bir inceleme. XIII. Ulusal Eğitim Bilimleri Kurultayı, 6-9 Temmuz 2004 İnönü Üniversitesi, Eğitim Fakültesi, Malatya, Tüerkiye.

Poyraz, H. \& Dere, H. (2001). Okulöncesi Eğitiminin İlke ve Yöntemleri. Ankara, Türkiye: Anı Yayıncılık.

Prevost, R. (2003). Much more a learning center. Canada: Trafford Publishing, ISBN-10: 1412002109 ISBN-13: 978-1412002103

Scraf, S., Eisenberg, M., \& Deater-Deckard, K. (1994). Measurement of quality in child care centers university of Virginia. Early Childhood Research Quarterly, 9;131-151.

Sak, Ş., T.I.., Sak, R., \& Tuncer, N. (2013). Influence of the physical environment on instruction process and behavior management: early childhood teachers' perceptions. Cumhuriyet International Journal of Education-CIJE e-ISSN: 2147-1606 Vol 2 (4), 38-46

Sanoff, H. (1995). Creating environment for young children. Washington D.C.: National Endowment for the Arts. North Carolina University.

Solak, N. (2007). Adana il merkezinde bulunan okulöncesi eğitim kurumlarında kalitenin incelenmesi. Published master thesis, Çukurova Üniversitesi, Social Sciences Institute, Adana.

Stanković, D. \& Stojić, J. (2007). Psycho-developing needs of children and spatial features for children’s stay. Architecture and Civil Engineering, 5(1), 71-75, UDC 725.573:15922.7(045)=111

Stephens, K. (1996). The child care professional. USA: Mc Graw Hill.

Tekmen, B. (2005). Ankara ilindeki okulöncesi eğitim kurumlarının yapısal ve işlevsel kalitesi üzerine bir çalışma. Unpublished master thesis, Orta Doğu Teknik Üniversitesi, Social Sciences Institute, Ankara.

Uçar (2007). Okul öncesi eğitim kurumlarında var olan ilgi köselerinin tespit edilmesi, ilgi köselerinin düzenlenmesi sırasında ortaya çıkan sorunlar ve çözüm önerileri ile ilgili ögretmen görüşleri. Published master thesis, Çanakkale On Sekiz Mart Üniversitesi, Çanakkale.

Ural, O., \& Ramazan, O. (2007). Türkiye’de okul öncesi eğitimin dünü ve bugünü. S. Özdemir, H. Bacanl, M. Sözer (Ed.). Türkiye'de Okul Öncesi Eğitim ve İlköğretim Sistemi Temel Sorunlar ve Çözüm Önerileri içinden. Ankara. Türkiye: Türk Eğitim Derneği,

Ünüvar, Ü. (2011). Okul öncesi ĕgitimde kalitenin geliştirilmesine ilişkin idareci, ögretmen ve veli görüşleri. Unpublished master thesis, Selçuk Üniversitesi, Sosyal Bilimler Enstitüsü, Konya.

Yalçın, M. (2011). Okulöncesi eğitim mekânlarında fiziksel çevrenin çocuk gelişimine etkisi ve mekân oluşumunu etkileyen psiko-sosyal belirleyiciler. Sanatta yeterlilik tezi, Hacettepe Üniversitesi, Ankara.

Yazıcı Z., Yellice B. \& Özer D. (2003), Okulöncesi eğitim ortamlarının değerlendirilmesi üzerine bir inceleme. Omep 2003 Dünya Konsey Toplantısı Ve Konferansı. Cilt III. 113-123. İstanbul, Türkiye: Ya-Pa Yayınları.

Yıldırım,A. \& Şimşek, H. (2008). Sosyal Bilimlerde Nitel Araştırma Yöntemleri (6. Bask1). Ankara, Türkiye: Seçkin Yayıncılık.

West, T.L. (2011). Environments for young children: a qualitative study and design of health and nurturing preschool environments. Yayınlanmış yüksek lisans tezi, The Florida State Unıversıty College of Vısual Arts, Theatre, and Dance, Florida, 
Wood, E.A. (2014). Free choice and free play in early childhood education. Troubling the International Journal of Early Years Education, 22(1), 4-18. doi.org/10.1080/09669760.2013.830562

Woolfolk, A. (2012). Educational Psychology (12th edition). New Jersey, USA: Prentice Hall PTR. ISBN 9780132613163. 


\section{TÜRKÇE GENIŞLETILMIŞ ÖZET}

Öğrenme merkezleri okul öncesi eğitim kurumlarında öğrenme ortamının temel bileşenidir ve çalışma alanı, etkinlik alanı, etkinlik köşesi, istasyon gibi tanımlamaları yapılmaktadır. İkinci öğretmen olarak görülen fiziksel çevrenin önemli bir parçası olan öğrenme merkezleri çocuklara deneme ve keşfetme firsatı sağlayan çocukların küçük grupla ya da bağımsız olarak çalıştığı bir yerdir ve öğrenme merkezleri farklı materyalleri içermekte, fiziksel olarak sınırları belirgin, birçok deneyimin ve etkinliğin oluştuğu bir alan özelliğine sahiptir. Çocuğun tüm gelişim alanına önemli katkıları olan öğrenme merkezlerinin düzenlenmesi beklenen yararın sağlanabilmesi ve programın amacına ulaşmasında önemli bir süreç olarak görülmektedir. Öğrenme merkezlerinin düzenlenmesinde birinci derecede sorumlu olan öğretmenin bir takım noktaları göz önünde tutması gerektirmektedir. Öğrenme merkezleri oluşturulurken çocukların yaş, gelişim özellikleri, büyüme, ilgi ve yeteneklerinin yanında merkezlerin birbiriyle olan ilişkisi, bazı merkezlerin doğal ışık, ışıklandırma gibi özel düzenleme gerektirmesi, çocuk sayısı ve sınıfın büyüklüğüne göre kaç merkezin oluşturulacağı ve merkezlerin genişliği gibi temel noktaların göz önünde tutulması gerekmektedir. Bununla birlikte çocuklara farklı öğrenme firsatı sunacak farklı merkezlerin oluşturulması, küçük sınıfların iki merkezli olması, merkezlerin belirli aralıklarla güncellenmesi ve amaca uygun materyallerin eklenmesi ve en önemlisi merkezleri birbirinden ayrılması, merkezlerde bulunacak çocuk sayısını merkezleri büyüklüğüne göre belirlemesi gibi yollara gidilebilmektedir. Merkezlerde bulunan materyallerin nasıl kullanacağı, merkezlerin düzenli tutulması gibi kuralların oluşturulasıda merkezlerin amacına uygun kullanımına sağlamaktadır.

Türkiye'de okul öncesi eğitimde önemli bir yere sahip olan fiziksel çevre ile ilgili yapılan çalışmaların fiziksel mekânın değerlendirilmesi, gelişime etkisi, bazı merkezlerdeki uygulamaların incelenmesi gibi belli alanlar üzerinde yoğunlaştığ1 görülmektedir. 2013 yılında güncellenen Okul Öncesi Eğitim Programında öğrenme merkezlerinin önemi vurgulanmış ve düzenlenmesi ile ilgili geniş açıklamalara yer verilmiş̧ir. Bu çalışmada öğretmenlerin öğrenme merkezlerini düzenleme ve kullanım durumlarını belirlemek, öğrenme merkezlerinde yaşadıkları sorunları ortaya koymak amaçlanmıştır.

Okul öncesi eğitim kurumlarında bulunan öğrenme merkezlerindeki uygulamaların yerinde incelenmesi amacıyla yapılan çalışma tarama modelinde olup nitel ve nicel araştırma yöntemlerinin bir arada kullanıldığ karma bir yöntem ile gerçekleştirilmiştir. Çalışma grubu 2014-2015 eğitim öğretim yılında Aydın il merkezinde Milli Eğitim Bakanlığı'na bağlı altı bağımsız anaokulu ile bünyesinde anasınıfı olan 27 ilköğretim okulundan rastgele seçilen altı anaokulu, dokuz anasınıfı öğretmeni olmak üzere toplam 15 öğretmenden oluşmaktadır.

Araştırmada veriler yapılandırılmış gözlem ve görüşme yöntemleri kullanılarak elde edilmiştir. Gözlem formu hazırlamak için araştırmacı tarafından alanla ilgili literatür taranmış, Milli Eğitim Bakanlığı Temel Eğitim Genel Müdürlüğü tarafından 2013 yılında güncellenen okul öncesi eğitim programındaki öğrenme merkezlerine ilişkin noktalar göz önüne alınmış, okul öncesi eğitim kurumlarındaki sınıflar incelenmiş ve öğretmenlerin görüşleri alınarak öğrenme merkezlerinin düzenlenmesi ve kullanımına yönelik iki bölümden oluşan bir gözlem formu oluşturulmuştur. Öğrenme Merkezleri Değerlendirme Gözlem Formu'nun ilk bölümünde "merkezlerin düzenlenmesine” yönelik 11, ikinci bölümünde "merkezlerin kullanımına" yönelik sekiz olmak üzere toplam 19 gözlem durumu yer almaktadır. Üçlü dereceli ölçeğin kullanıldığı form; "var", "yok" ve "kısmen” biçiminde derecelendirilmiş, her bir gözlem durumunun yanına gözleme yönelik açıklama kısmı eklenmiştir. Öğretmen Görüşme Formu ise gözlenen sınıf ve sınıf öğretmeni ile ilgili genel bilgilerin yer aldığı altı ve sınıf öğretmeninin öğrenme merkezlerine ilişkin görüşlerine yönelik altı olmak üzere 12 görüşme sorusundan oluşmaktadır. Ayrıca öğretmenlerin yaş, cinsiyet, çalışma yılı, mezun olduğu okul, sınıflarında bulunan çocuk sayısı ve sınıfın genişliğine yönelik beş sorunun yer aldığı Genel Bilgi Formu kullanılmıştır. Veri toplama sürecinde gerekli izinler alınıp yönetici ve öğretmelere araştırmanın amacı açıklandıktan sonra her sınıfta "merkezlerin düzenlenmesi" ile ilgili bölümde yer alan gözlem durumları araştırmacı tarafından sınıf ve sınıftaki materyaller gözlemlenerek kaydedilmiştir. Öğrenme "merkezlerinin kullanımı" ile ilgili bölüm ise; her sınıf için farklı üç günde yapılan gözlemlerle elde edilmiştir. Gözlem çocukların okula gelişinden merkezlerde oyun saatinin bitimine kadar geçen sürede yapılmıştır. Üç günlük gözlemler ayrı formlara kaydedilmiş ve üç günün sonunda gözlemler incelenerek ortak bir puan elde edilmiştir. Öğretmen görüşlerine yönelik form ise öğretmenler tarafindan doldurulmuştur.

Verilerin analizinde betimsel ve içerik analiz yöntemlerinin kullanıldığ çalışmada önceden oluşturulan temalar kullanılmıştır. Öğrenme merkezlerinin düzenlenme durumu teması, "öğrenme merkezlerinin 
mekân özellikleri" ve "öğrenme merkezlerinin materyal özellikleri" olmak üzere iki, öğrenme merkezlerinin kullanım durumu teması ise; "öğrenme merkezlerinde çocuk bulunma durumu", "öğrenme merkezlerinde çocukların yaralanma durumu" ve "öğretmenin öğrenme merkezlerinde çocukları gözlemleme durumu" olmak üzere üç alt tema üzerinden tanımlanmaya çalışılmıştır. Öğretmenlerin öğrenme merkezlerini düzenleme ve kullanımına yönelik yeterlik durumları ise içerik analizi yoluyla saptanmıştır

Öğrenme merkezlerindeki uygulamaların incelenmesi amacıyla yapılan bu çalışmada, öğretmenlerin öğrenme merkezlerini düzenleme ve kullanımına yönelik verdikeri cevaplardan yola çıkarak kendilerini yeterli gördükleri, ancak gözlem sonucunda öğretmenlerin bilgi ve beceri düzeylerinin düşük olduğu görülmüştür. Öğrenme merkezlerinin etkin kullanımı ve çocukların farklı markezlerden yararlanma durumlarının göz önünde tutulmadığı, merkezlerin materyal yönünden desteklenmediği ve öğretmenlerin çocuklar merkezde oyun oynarken onları gözlemleme yoluna gitmedikleri belirlenmiştir. Öğrenme merkezlerindeki uygulamalara yönelik çok az sayıda yapılan çalışma sonuçları öğrenme merkezlerinin öğretmenler tarafından düzenlenmesi ve kullanımına ilişkin çeşitli nedenlere bağlı olarak bazı yetersizliklerin olduğunu göstermektedir. Bu düşüncelerden yola çıkarak öğretmenlere; öğrenme merkezlerinin önemi, amacı, düzenlenmesi, etkin ve amaca uygun kullanımı, çocukları merkezlerdeki etkinlikleri sırasında gözlemlemeleri, çocuklar arası iletişim, oyun içerikli etkileşim ve çocuk öğretmen arasındaki etkileşim gibi konulara yönelik bilgi ve beceri düzeylerini arttırmaları gerekliliği önerilebilir. Çalışma bulguları 1şı̆̆ında araştırmacılara; öğrenme merkezlerinin çocukların gelişimi etkin, kalıcı ve sürdürülebilir öğrenmeye etkilerine ilişkin deneysel çalışmalar yaparak merkezlerin düzenlenmesi ve kullanımına ilişkin bir bilinci oluşturmaları önerilmektedir. Milli Eğitim Bakanlığı Destek Hizmetler Birimi Eğitim Araçları ve Yayımlar Daire Başbakanlığı ve özel kuruluşların okul öncesi eğitim kurumlarında bulunması gereken malzemelerin nitelikleri konusunda, çok disiplinli bir bakış açısı ile üretilmesi için gerekli işbirliğinin sağlanması önerilmektedir. 